\title{
PERANAN SOSIOLINGUISTIK DALAM PENGAJARAN BAHASA: SEBUAH KAJIAN TEORETIS DAN PENERAPANNYA (TEMUAN LINGUISTIK UNTUK PENGAJARAN BAHASA)
}

\author{
Dwi Setiyadi *
}

\begin{abstract}
Language and the speech society can not even be separated to each other, because when there is a language, there will be a speech community and vice-versa. Langauge has even become one of condition of society. The existence and use of the language in society is learned through sociolinguistics, which views language as a means of communication rather than a system alone, bearing varieties in line with the given social domains. On the other hand, the traditional language teaching has regarded language as a system, which entails structuralism models of teaching. In the development of the language teaching methods, language is not merely seen as a system, rather than a communication tool, just as sociolinguistics have suggested. This articles discusses the role of sociolingusitics in the development of teaching models, beginning from the nature of speech community, language function up to sociolinguistics-based language teaching models.
\end{abstract}

Key words: Sociolinguistics, Language Teaching

\begin{abstract}
Abstrak
Bahasa dan masyarakat tidak pernah bisa dipisahkan satu dengan yang lainnya, karena di mana ada masyarakat, di situ ada bahasa, dan sebaliknya. Dengan demikian bahasa menjadi salah satu syarat keberadaan suatu masyarakat tertentu. Keberadaan bahasa dalam masyarakat dipelajari melalui sosiolinguistik, yang memandang bahasa sebagai alat komunikasi antaranggota masyarakat dengan variasi-variasinya sesuai dengan ranah sosialnya. Di lain pihak, pengajaran bahasa tradisional memandang bahasa sebagai sistem, sehingga melahirkan pengajaran bahasa strukturalis. Dalam perkembangannya, para proponen metode pengajaran bahasa menyadari bahwa bahasa bukan sekedar sistem, namun lebih merupakan alat komunikasi, sebagaimana yang dipelajari melalui sosiolinguistik. Kajian ini membahas bagaimana peranan sosiolinguistik dalam perkembangan pengajaran bahasa, mulai dari
\end{abstract}

* Dwi Setiyadi adalah Dosen Program Studi Pendidikan Bahasa Inggris IKIP PGRI Madiun dan Kandidat Doktor Universitas Negeri Sebelas Maret 
karakteristik masyarakat bahasa, fungsi bahasa, sampai pada modelmodel pengajaran bahasa yang berbasis sosiolinguistik.

Kata kunci: Sosiolinguistik, Pengajaran Bahasa

\section{A. Pendahuluan}

Bahasa merupakan salah satu bagian penting di dalam masyarakat dan bermasyarakat, bahkan bahasa tidak bisa dipisahkan dari masyarakat. Di mana ada masyarakat, maka di situ akan ada bahasa, dan sebaliknya, di mana ada bahasa di situ pasti ada masyarakat bahasa yang menggunakannya sebagai alat berinteraksi (Trudgil, 1982). Jika dikaji lebih mendalam, maka komponen-komponen dari masyarakat di antaranya adalah adanya sekumpulan orang, yang menduduki suatu areal tertentu, memiliki kultur yang sama, menjunjung nilai-nilai dan normanorma yang sama, serta saling berinteraksi (Holmes, 2001). Interaksi yang dilakukan antara anggota masyarakat dengan menggunakan bahasa, sehingga jelaslah bahwa bahasa merupakan bagian dari mayarakat. Bahkan tidak bisa dibayangkan jika suatu masyarakat tidak memiliki bahasa, maka namanya bukan masyarakat.

Interaksi merupakan sifat dasar yang dimiliki oleh setiap manusia di dalam masyarakatnya, dan bahasa menjadi satu sarana terpenting untuk terjadinya sebuah interaksi tersebut (Soebroto, 2007). Namun kita semua juga mengerti bahwa tidak semua orang di seluruh dunia menggunakan satu bahasa yang sama. Agar proses interaksi di antara masyarakat yang memiliki bahasa yang berbeda tetap berjalan dengan baik, maka di antara mereka perlu sebuah pemahaman atau kesepakatan mengenai makna dalam bahasa yang mereka gunakan (Hymes, 1987). Hal inilah yang menjadikan dasar perlunya sebuah pengajaran dan atau pembelajaran bahasa di dalam masyarakat. Komunikasi antaranggota masyarakat, terutama yang memliki perbedaan bahasa, akan menjadi lancar ketika di dalam masyarakat tersebut telah terjadi proses pembelajaran bahasa, yang dilakukan secara formal maupun informal.

Berdasarkan dasar pemikiran sebagaimana diuraikan di atas, pengajaran bahasa menjadi salah satu bidang terpenting yang dibahas dalam perkembangan ilmu pengetahuan, utamanya bidang pengajaran. Tidak heran bahwa teori-teori yang berkaitan dengan bahasa dan pengajaran bahasa juga berkembang sejalan dengan perkembangan peradaban manusia. Perkembangan teori bahasa dan pengajaran bahasa tersebut memiliki sejarah tersendiri di dalam khasanah ilmu yang berkembang di dunia (Richards, 2001). Hal itu bisa dikaji melalui perubahan-perubahan yang terjadi dalam teori yang berkaitan dengan pengajaran bahasa.

Kemajuan demi kemajuan yang dicapai oleh teori bahasa memiliki dampak yang secara langsung maupun tidak langsung terhadap teori pengajaran bahasa, bahkan bisa dikatakan bahwa teori bahasa tersebut menjadi dasar filosofis dari teori pengajaran bahasa. Dengan demikian teori bahasa yang berkembang pada suatu era tertentu akan tercermin atau mempengaruhi teori pembelajaran bahasa pada era tersebut (Oliva, 1982). Misalnya, perkembangan teori linguistik 
struktural pada tahun 1920-an sampai dengan tahun 1970-an berpengaruh sangat kuat terhadap teori pengajaran bahasa seperti: Metode Audiolingual dan Grammar Translation Method.

Teori linguistik struktural tersebut melihat bahwa bahasa merupakan suatu struktur kata-kata yang memiliki keberaturan, dan mempelajari bahasa artinya mempelajari struktur bahasa tersebut (Richards, 2001). Perkembangan teori linguistik berikutnya, pada tahun 1970-an sampai sekarang, yang dimulai oleh Chomsky, yang mengatakan bahwa bahasa tidak sekedar struktur korpus sebagaimana dikemukakan oleh para strukturalis, namun lebih merupakan struktur batin yang mendasari kemampuan berbahasa secara keseluruhan (Aitchison, 1984). Kemudian teori sosiolinguistik Hymes menyempurnakan dasar-dasar teori Chomsky mengenai kemampuan berbahasa melalui konsep communicative competence.

Hymes (1979) menyatakan bahwa kompetensi bahasa seseorang ditandai dengan pengetahuan yang menyeluruh mengenai sistem bahasa yang dimaksud, termasuk penggunaannya dalam komunikasi riil. Konsep communicative competence yang disampaikan oleh Hymes tersebut memengaruhi perkembangan teori pengajaran bahasa sampai sekarang, dengan munculnya metode-metode pengajaran bahasa seperti: Communicative approach dan competency-based language teaching.

\section{B. Pembahasan}

\section{Prinsip-prinsip Dasar Sosiolinguistik}

Bahasa secara sosiolinguistis bukan hanya merupakan struktur kata-kata saja, namun bahasa juga merupkan alat interaksi sosial yang mencerminkan keseluruhan konstruk masyarakat pemakai bahasa tersebut (Fishman, 1974). Berdasarkan pada pendapat tersebut, maka ada beberapa hal yang penting berkaitan dengan bahasa, yang dibahas pada subbab ini.

\section{a. Hubungan Bahasa dengan Masyarakat}

Salah satu sifat alami bahasa adalah bahwa bahasa itu arbitrer, yang diciptakan sewenang-wenang oleh masyarakat bahasa tersebut (Soebroto, 2007), artinya bahwa tidak ada hubungan (langsung) antara bentuk bahasa dengan makna yang dimasud dalam bahasa itu. Dengan sifatnya yang arbitrer, maka kita tidak akan bisa mengetahui alasannya mengapa suatu bentuk kata (bahasa) digunakan untuk mengacu pada suatu makna tertentu pada suatu bahasa tertentu (Francis, 1972). Sehingga bahasa diciptakan bebas oleh masyarakat pemakainya. Satusatunya pemabatas dari sifat arbitrer bahasa itu adalah konvensi sosial. Artinya, bahwa proses penciptaan bahasa tidak terikat oleh sesuatu apa pun kecuali konvensi sosial.

Sebagai produk dari sebuah konvensi sosial, maka bahasa tidak bisa dipisahkan dari masyarakat bahasa tersebut; bahkan bahasa merupakan salah satu bagian dari faktor-faktor yang membentuk masyarakat. Dari dasar pemikiran tersebut tercermin suatu hubungan sangat erat antara bahasa dengan masyarakatnya, sehingga semua faktor yang membentuk masyarakat akan 
mempengaruhi bahasa yang dipakainya, dan sebaliknya, bahasa yang diapakai oleh masyarakat itu berpengaruh terhadap masyarakatnya (Trudgil, 1974).

\section{b. Bahasa sebagai Perilaku Sosial}

Labov menyatakan bahwa bahasa adalah perilaku sosial (Trudgil, 1974). Bahasa bukan saja susunan kata-kata, namun dibalik susunan kata-kata itu terdapat nilai-nilai sosial yang dijunjung tinggi oleh masyarakat bahasa itu. Orang, sebagai anggota sebuah masyarakat, akan selalu terikat dengan nilai-nilai tersebut ketika menggunakan bahasa itu. Seseorang tidak akan pernah meninggalkan nilainilai sosial tersebut dalam menggunakan bahasanya atau akan memiliki risiko dianggap tidak sopan.

Misalnya, masyarakat Jawa di dalam menggunakan Bahasa Jawa akan selalu terikat dengan unggah-ungguh (sopan santun berbahasa) yang mencerminkan adanya "hubungan-peran" di antara pemakai bahasa sebagai nilai yang harus ada dalam pemakaian bahasa tersebut. Kesalahan dalam menerapkan unggah-ungguh ini akan berakibat pada terganggunya hubungan antara pemakai bahasa tersebut meskipun secara harfiah makna dari kata-kata tersebut sama (Suseno, 1991). Contohnya ada pemuda yang mengatakan dengan bahasa Jawa: "kulo badhe tindak".

Orang (Jawa) yang diajak berbicara pasti akan merasa terganggu dengan pilihan kata yang "tidak tepat" tersebut, karena pilihan kata tersebut membawa suatu nilai sosial tertentu, meskipun dari segi makna kata (harfiah) sudah cukup mewakili maksud si pemakai bahasa. Dengan demikian, bagaimana orang berperilaku akan ditunjukkan dalam bahasa yang dipakainya. Bahkan bahasa akan mampu menunjukkan kondisi dan situasi pemakainya, dari golongan kelas sosial yang mana, tempat asal, bahkan sedang dalam kondisi kebatinan seperti apa.

\section{c. Domain Sosial dan Variasi Bahasa}

Domain sosial adalah keseluruhan konstruk masyarakat di mana suatu bahasa digunakan (Fishman, 1972). Domain sosial meliputi konteks sosial (speech events) seperti setting, peserta tutur, topik pembicaraan, hubungan peran, okupasi, dan situasi (Hymes, 1972). Domain sosial tersebut akan berpengaruh sangat besar terhadap bahasa yang dipakai oleh pemakai bahasa itu. Kecuali rasa bahasa yang diakibatkan oleh perbedaan domain, ada hal yang lebih penting yaitu variasi bahasa.

Variasi bahasa, yang secara spesifik disebut sebagai dialek suatu bahasa, disebabkan secara langsung oleh perbedaan domain sosial tersebut (Giglioli, 1974). Misalnya perbedaan setting (atau tempat) mengakibatkan perbedaan dialek suatu bahasa, sehingga ada bahasa Jawa dialek suroboyo-an yang dipakai oleh masyarakat Surabaya, ada bahasa Jawa dialek surokarto-hadiningratan yang dipakai oleh masyarakat Solo dan sekitarnya, ada pula bahasa Jawa tegalan yang dipakai oleh masyarakat Tegal dan sekitarnya (Suseno, 1991). Dialek-dialek yang disebabkan karena perbedaan tempat tersebut selanjutnya disebut sebagai geographical dialect. Masing-masing domain sosial tersebut memiliki tipe variasi bahasa yang ditimbulkannya. Dalam tulisan singkat ini tidak akan membahas 
semua tipe variasi tersebut. Ilustrasi tersebut hanya digunakan untuk mendapatkan kepastian teoretis bahwa konteks berpengaruh terhadap pemakaian bahasa.

\section{d. Pilihan Bahasa dan Interferensi}

Kerangka dialek yang disebabkan karena konteks yang berubah-ubah, pilihan bahasa (code) dan interferensi merupakan fenomena bahasa yang sangat menarik (Pride and Holmes, 1974). Masyarakat pemakai bahasa akan selalu dihadapkan pada pilihan dialek tertentu pada konteks tertentu sebagaimana diilustrasikan terdahulu. Dengan demikian tidak ada satu dialek pun yang bisa dipakai dalam semua situasi atau konteks, bahkan dialek yang dikatakan sebagai variasi standard juga tidak memilki kemampuan untuk dipakai dalam semua konteks situasi. Artinya bahwa setiap konteks situasi memiliki variasi bahasanya sendiri-sendiri dalam bahasa tertentu. Sehingga pemahaman atas suatu bahasa akan salah jika hanya mencakup satu variasi saja (misalnya variasi standar). Memahami bahasa artinya memahami seluruh sistem yang dimiliki oleh bahasa tersebut termasuk bagaimana menggunakan bahasa tersebut dalam konteks situasi yang berbeda-beda (Hymes, 1972).

Interferensi antar (variasi) bahasa juga menjadi fenomena yang muncul di dalam pemakaian bahasa oleh masyarakat bahasa itu. Interfernsi diartikan sebagai pemakaian sistem bahasa tertentu di dalam bahasa yang lain (Fishman, 1972). Sedangkan Soebroto (2007) menyatakan bahwa interferensi merupakan kontak antarkode (bahasa) pada pemakai bahasa yang disebabkan karena adanya penguasaan dua (kode) bahasa atau lebih. Dalam hal ini bahasa memiliki variasi, dan di antara variasi tersebut bisa terjadi interferensi di dalam pemakaian riil oleh masyarakat bahasa tersebut. Dengan demikian bentuk-bentuk bahasa (dengan interferensi) semacam ini juga perlu dipahami oleh pembelajar bahasa, sehingga mereka bisa memiliki pemahaman menyeluruh tentang bahasa dan masyarakat pemakai bahasa tersebut, setidaknya memiliki pemahaman bahwa interferensi sangat mungkin terjadi pada pemakaian bahasa secara riil.

\section{e. Fungsi Bahasa}

Sebagai alat komunikasi, bahasa memiliki berbagai fungsi, di antaranya alat untuk tukar-menukar informasi, alat untuk mengekspresikan ide, alat untuk mempertahankan nilai kebanggaan kelompok, dan sebagainya, bahkan sampai pada fungsi untuk mempertahankan hubungan sosial (Robinson, 1974). Dalam beberapa hal, pemakai bahasa lebih terikat kepada fungsi bahasa daripada kepada bentuk bahasa, di mana makna bahasa seringkali tidak konsisten dengan bentuk yang dipilihnya. Misalnya: pada suatu keluarga suami belangganan koran, pada suatu pagi si suami bertanya kepada istrinya, "Jam piro, Bu?" (Sekarang sudah jam berapa, Bu?); kemudian istrinya menjawab, "Kae lho korane wis teko" (Itu lho korannya sudah datang) (Soebroto, 2007).

Pertanyaan suami kepada istrinya tidak benar secara structural, namun si istri paham atas pertanyaan tersebut. Sedangkan jawaban si istri seolah-olah tidak menjawab pertanyaan suaminya juka bahasa hanya dilihat sebagai bentuk (makna) harfiah saja. Tetapi si suami tahu bahwa saat itu jam 07.00 karena memang biasanya koran datang jam 07.00 (Soebroto, 2007). Ilustrasi ini hanya akan 
digunakan untuk menunjukkan bahwa pemakaian bahasa dalam fungsinya sebagai alat komunikasi di dalam masyarakat bahasa jauh dari sekedar bentuk urutan katakata. Sehingga dalam mempelajari suatu bahasa mestinya sampai pada tataran ini, tidak hanya mempelajari bentuk dan makna harfiah namun juga bagaimana masyarakat bahasa menggunakan bahasa tersebut.

\section{Konsep-konsep Sosiolinguistik dalam Pengajaran Bahasa}

Banyak teori linguistik yang memberikan sumbangan terhadap pengajaran bahasa di dunia maupun di negeri ini. Pada kurun waktu 1920-an sampai pada tahun 1970-an banyak pengaruh linguistik struktural pada pengajaran bahasa. Baru pada tahun 1970-an sampai sekarang pengaruh berkembangnya teori sosiolinguistik nampak pada pengajaran bahasa. Cognitive code yang disampaikan oleh Chomsky, yang kemudian disempurnakan oleh Hymes dengan konsepnya communicative competence memberikan corak dan warna baru pada pengajaran bahasa di dunia. Sejak saat itu sampai sekarang berkembang pendekatanpendekatan dan metode-metode pembelajaran bahasa yang mengacu pada prinsip communicative competence sebagaimana disampaikan Hymes, sedangkan pendekatan pembelajaran bahasa yang mengacu pada teori linguistik struktural mulai banyak ditinggalkan. Berikut adalah beberapa pendekatan dan metode pembelajaran bahasa yang dijiwai oleh teori sosiolinguistik.

\section{a. Competency-based Language Teaching}

Diawali pada tahun 1970-an, pembelajaran bahasa didasarkan pada kemampuan berbahasa yang beorientasi pada pekerjaan dan pertahanan hidup yang diperuntukkan bagi pembelajar dewasa (Richards, 2001: 141). CBLT medasarkan filosofinya pada perspektif fungsional dan interaksional bahasa secara alami. Metode pembelajaran bahasa ini disusun berdasarkan communicative competence dan berusaha untuk mengembangkan kemampuan berbahasa secara fungsional. Dalam banyak hal CBLT memiliki kesamaan ciri dengan communicative language teaching.

\section{b. Communicative Language Teaching}

Sebagai tanggapan terhadap Chomsky (1957) yang menyebutkan adanya "kreativitas" dalam penggunaan bahasa oleh pemakainya, maka banyak pendapat yang muncul bahwa metode-metode pengajaran bahasa yang menggunakan teori linguistik struktural sebagai landasan filosofisnya tidak lagi layak untuk diteruskan. Diawali dengan teori Hymes (1987) mengenai communicative competence, bahasa dilihat sebagai alat komunikasi, sehingga kemampuan berbahasa dilihat dari kemampuan seseorang untuk menggunakannya dalam komunikasi.

Menurut Hymes kompetensi komunikatif meliputi keseluruhan pemahaman tentang sistem bahasa, beserta penerapannya dalam komunikasi riil (Richards, 2001:159). Sedangkan menurut Chomsky, competence diartikan sebagai struktur batin yang mendasari komunikasi dengan menggunakan kalimat yang tak terhitung jumlahnya (Aitchison, 1976). Dalam penerapannya, pendapat Hymes digunakan sebagai landasan filosofis dari Communicative Language 
Teaching. Communicative Language Teaching menekankan pembelajaran bahasa dari dimensi komunikasi.

Prinsip-prinsip komunikasi yang dimaksudkan dalam model pembelajaran ini meliputi: (1) aktivitas, yang melibatkan komunikasi riil sebagai objek pembelajaran; (2) task principle, aktivitas yang mengguanakan bahasa untuk menjalankan tugas bermakana digunakan sebagai objek pembelajaran; dan (3) prinsip kebermaknaan, bahasa yang bermakna bagi pembelajar merupakan objek pembelajaran. Akibatnya aktivitas pembelajaran dipilih sesuai dengan tingkatan sejauh mana siswa bisa telibat di dalam penggunaan bahasa yang bermakna dan authentic. Selanjutnya, Communicative Language Teaching sering diterapkan sebagai Communicative Approach (Savignon, 1983).

\section{c. Natural Approach}

Prinsip dasar dari natural approach sama dengan communicative approach, yaitu melihat bahasa sebagai alat komunikasi yang wajar. Dalam penerapannya sebagai metode pembelajaran, natural approach menekankan prinsip naturalistik yang lebih banyak mengedepankan keterlibatan (exposure) dalam bahasa target. Keterlibatan secara langsung dalam pemakaian bahasa target secara natural akan memungkinkan terjadinya pemerolehan bahasa (language acquisition) (Richards, 2001:179). Prinsip dari natural approach adalah pengembangan kompetensi bahasa target dengan proses "akuisisi" bahasa secara natural.

\section{d. Cooperative Language Learning}

Born to Talk merupakan landasan pembelajaran bahasa dalam cooperative language learning (Weeks, 1979). Bahasa sebagai objek pembelajaran dilihat sebagai alat untuk melakukan interaksi sosial di dalam masyarakat. Dalam kehidupan sehari-hari manusia banyak dilibatkan dalam percakapan (penggunaan bahasa) dalam kerangka interaksi sosial. Sedangkan percakapan di antara anggota masuarakat terikat oleh sebuah tatanan (aturan/nilai) yang disepakati di antara mereka (Richards, 2001: 193). Grammar (bentuk bahasa) akan banyak bergantung dari nilai-nilai suatu masyarakat pada suatu saat tertentu dan pada tempat tertentu.

Keempat metode pembelajaran bahasa tersebut merupakan metode yang paling banyak dipakai dalam pembelajaran bahasa. Ada beberapa metode pembelajaran bahasa yang lain yang mendasarkan pada teori sosiolinguistik diantaranya: content-based language teaching, task-based language teaching, dan sebagainya. Dengan demikian metode pembelajaran bahasa yang sekarang berkembang, didasarkan pada teori sosiolinguistik dan meninggalkan (meskipun tidak seluruhnya) prinsip-prinsip teori struktural.

\section{Pembelajaran Bahasa di Sekolah}

Perubahan metode-metode pembelajaran sebagaimana dijelaskan di atas terjadi secara internasional. Di Indonesia sendiri, perubahan seperti tersebut di atas juga terjadi. Perubahan tersebut tercermin di dalam kurikulum yang diberlakukan secara nasional di Indonesia. Kurikulum 1994 mengadopsi nama 
Communicative Approach, khusus untuk pembelajaran bahasa yang mendasarkan pada teori sosiolinguistik sebagaimana dijelaskan pada subbab sebelumnya. Perkembangan kurikulum selanjutnya ialah Kurikulum 2004 atau Kurikulum Berbasis Komptensi. Dilihat dari nama kurikulum tersebut sudah memperlihatkan adanya pengaruh dari teori sosiolinguistik di dalam kurikulum pengajaran (bahasa) di Indonesia.

Bahkan nama-nama dari kurikulum yang saat ini diberlakukan diambil secara langsung dari nama metode-metode pembelajaran yang berkembang pada era yang dipengaruhi oleh teori sosiolinguistik tersebut. Kurikulum pengajaran bahasa di Indonesia sudah barang tentu berada dalam kerangka Communicative Approach atau Kurikulum Berbasis Kompetensi. Subbab ini secara khusus membahas konsep-konsep teori sosiolinguistik yang secara langsung maupun tidak langsung berpengaruh di dalam pembelajaran bahasa di sekolah.

Kurikulum berbasis kompetensi dan pendekatan komunikatif untuk pengajaran bahasa merupakan topik pokok dalam subbab ini. Secara teknis oprasional dalam pengajaran bahasa, penerapan kurikulum berbasis kompetensi dan communicative approach banyak memiliki kesamaan, karena dasar filosofis (teori sosiolinguistik) yang dipakai di dalam sama. Berikut ini adalah pemaparan mengenai dasar-dasar teori sosiolinguistik yang diterapkan di dalam pengajaran berbasis kompetensi di sekolah.

\section{a. Bahasa Sebagai Alat Komunikasi}

Salah satu konsep sosiolinguistik yang menonjol adalah bahwa bahasa, yang dalam hal ini digunakan sebagai objek belajar, dilihat sebagai alat untuk berkomunikasi. Pada kurikulum pengajaran bahasa sebelumnya (Kurikulum 1974) bahasa dilihat sebagai sekumpulan aturan (sistem), sehingga mempelajari bahasa dilakukan dengan mempelajari struktur-struktur yang ada di dalam bahasa target itu, mulai dari tata bunyi, tata kata, dan tata kalimat. Hasil belajar bahasa pada masa-masa tersebut adalah kemampuan untuk menggunakan tata bahasa yang baik dan benar dilihat dari sisi tata bahasanya. Namun cara belajar dengan pendekatan structural semacam ini dinilai seringkali mengalami kegagalan dalam komunikasi riil, di mana bahasa akan bervariasi berdasarkan pada domain sosial atau speech even yang belaku pada saat itu. Tata bahasa yang benar belum tentu komunikatif.

Pendekatan yang dipakai dalam kurikulum berbasis kompetensi, bukannya pendekatan struktural seperti tersebut di atas, namun pendekatan komunikatif. Bahasa dalam hal ini dilihat sebagai alat komunikasi antaranggota masyarakat. Sebagai alat komunikasi, bahasa akan digunakan oleh masyarakat bahasanya dalam konteks yang berbeda-beda. Di dalam proses pembelajaran bahasa, implikasi dari pendekatan sosiolinguistik tercermin di dalam strategi pembelajaran yang digunakan, yakni: pertama, aspek-aspek ketrampilan berbahasa (speaking, writing, listening, reading) dipelajari secara simultan, tidak terpisah-pisah. Hal ini dilakukan dengan menggunakan strategi belajar yang mendasarkan pada tema, yang digunakan untuk mempelajari keempat ketrampilan berbahasa tersebut.

Kedua, tugas-tugas instruksional dikaitkan dengan fungsi komunikatif bahasa secara riil. Untuk bisa mempelajarai bahasa sesuai dengan fungsinya di dalam masyarakat secara riil, maka tema dalam design instruksional diangkat dari 
kejadian nyata secara topikal. Di dalam masyarakat terdapat banyak bidang yang menuntut keahlian berbahasa secara khusus, dan berbeda dengan jenis kode dari bidang yang lain. Dengan demikian tugas instruksional didasarkan atas fungsi bahasa dalam bidang yang dimaksud, atau disebut sebagai task-based instruction.

Ketiga, berkaitan dengan item kedua di atas, sumber-sumber belajar bukan hanya buku teks yang diberikan oleh guru di dalam kelas, melainkan sumbersumber yang bersifat autentik, yaitu yang didapatkan pada penggunaan secara nyata dalam konteks tertentu (Mulyasa, 2004:72). Materi autentik bisa berupa: konteks riil, media masa, rekaman suatu kejadian yang memiliki nilai sebagai materi instruksional.

Keempat, setting belajar yang tidak dibatasi oleh tembok ruang kelas. Maksudnya adalah bahwa ruang kelas bukanlah satu-satunya tempat untuk belajar bagi siswa, namun di mana saja mereka bisa mendapatkan pengetahuan mengenai penggunaan bahasa dan memahaminya untuk kepentingan belajarnya. Masyarakat merupakan kelas di mana siswa bisa melakukan proses pembelajaran, namun tentunya siswa juga harus dibekali suatu metode dan ketampilan pembelajaran tertentu agar proses pembelajaran tersebut bisa berlangsung dalam setting yang sangat beragam.

\section{b. Ketrampilan Berbahasa Bersifat Menyeluruh}

Prinsip pembelajaran bahasa yang menyeluruh ini diilhami oleh konsep sosiolinguistik communicative competence yang dinyatakan oleh Hymes. Sebagai perbaikan dari konsep Chomsky, yang dimaksud dengan communicative competence oleh Hymes adalah untuk mampu berbahasa dengan baik, seseornag harus memiliki pemahaman tentang seluruh sistem bahasa itu serta penerapannya dalam konteks-konteks tertentu pula. Jadi orang dikatakan memiliki kompetensi bahasa tertentu jika ia mengerti aturan kebahasaan dari bahasa tersebut dan mampu menggunakannya dalam konteks yang dimaksud. Implikasi dari prinsip kompetensi bahasa ini tercermin dalam strategi pembelajaran sebagaimana dijelaskan berikut ini.

Pertama, strategi belajar tuntas (Mulyasa, 2004:27) yang memiliki pengertian bahwa dalam kondisi yang tertentu, setiap pembelajar akan mampu menguasai materi instruksional dengan baik. Hal yang membuat perbedaan antara pembelajar yang satu dengan yang lainnya hanyalah terletak pada faktor waktu. Bagi yang berbakat (talented) membutuhkan waktu penguasaan materi lebih pendek dibandingkan dengan pembelajar yang kurang berbakat. Dan jika masingmasing dari mereka diperlakukan sesuai dengan kondisinya masing-masing maka akan tercapai tujuan instruksional oleh semua pembelajar. Strategi pembelajaran ini memperhatikan pluralitas pembelajar dengan memberikan perlakuan yang berbeda, sehingga menjadi lebih human.

Kedua, tujuan instruksional disusun atas dasar kebutuhan akan ketrampilan bahasa yang dimiliki oleh siswa. Sebelum guru merumuskan tujuan instruksional, ia akan terlebih dahulu mengkaji ketrampilan bahasa seperti apa yang harus disajikan dalam pembelajaran (Mulyasa, 2004:72). Strategi ini akan memberikan kemanfaatan secara langsung mengenai ketrampilan berbahasa siswa yang diperoleh di dalam kelas. 
Ketiga, berkaitan dengan butir kedua di atas, tujuan instruksional berorientasi pada hasil belajar. Diharapkan bahwa grammar yang didapatkan siswa sesuai dengan penggunaan bahasa secara riil. Karena tugas-tugas instruksional selalu mengacu pada fungsi bahasa dalam konteks nyata, maka hasil belajar bisa diterapkan secara langsung dalam masyarakat bahasa.

Keempat, pendekatan pembelajaran yang digunakan berupa natural approach, di mana proses pembelajaran dilakukan dengan strategi yang paling denkat dengan kenyataan pemakaiab bahasa secara alamidan wajar. Dalam hal ini, tentunya materi instruksional bersifat autentik sebagaimana dijelaskan terdahulu. Bagaimana masyarakat mengunakan bahasa itu secara wajar, maka seperti itulah materi instruksional disusun.

\section{c. Pembelajar Merupakan Bagian dari Masyarakat Bahasa}

Pembelajar tidak dianggap sebagai orang yang siap untuk menerima apa saja untuk dipelajarinya, sebagaimana kertas kosong yang siap untuk ditulisi sesuai dengan kehendak guru (transfer of knowledge), namun pembelajar dilihat sebagai bagian dari masyarakat bahasa dengan segala perbedaan dan persamaannya dengan orang lain. Sebagai pribadi, siswa memiliki sikap, karakteristik, kemampuan, kecenderungan yang bisa sama dan bisa berbeda dengan orang lain. Mengapa semua siswa harus diberi sesuatu yang sama dengan cara yang sama untuk tujuan yang sama? Sebagaimana dilakukan pada pendekatan-pendekatan yang bersifat teacher-centered instruction. Siswa adalah manusia yang memiliki latar belakang yang unik. Implikasi dari sudut pandang ini dalam strategi pembelajaran nampak sebagaimana dijelaskan berikut.

Pertama, learner-centered approach di mana strategi pembelajaran lebih mendorong keaktifan siswa dalam melakukan proses pembelajaran. Dulu, proses pembelajaran sangat tergantung pada guru, namun dalam kerangka ini, siswalah yang altif dalam mencari informasi pembelajaran yang sesuai dengan tujuan instruksional (Mulyasa, 2004:72). Dalam proses pembelajaran, siswa akan mencari sebanyak-banyaknya informasi untuk pengembangan pengetahuannya dari sumber yang bervariasi. Strategi ini akan membentuk kemandirian serta kepercayaan diri siswa tentang kemampuannya untuk mencari informasi, bahkan untuk melakukan penilaian pada dirinya sendiri.

Kedua, fungsi guru sebagai fasilitator. Guru tidak lagi menjadi dalang yang menentukan segala hal yang terjadi di dalam kelas, namun siswalah yang menjadi subjek proses pembelajaran. Peranan guru hanya sebatas menetapkan tujuan instruksional, menetapkan tugas-tugas terkait, memfasilitasi proses yang dilakukan siswa, menjadi konsultan dan sebagainya. Learning experience yang seluas-luasnya merupakan tujuan dari proses pembelajaran dengan fungsi guru sebagai fasilitator dalam hal ini.

Ketiga, metode pembelajaran yang bervariasi. Dengan kondisi proses pembelajaran sebagaimana dijelaskan di atas, maka metode pembelajaran tidak terikat pada satu jenis saja, namun bisa dikembangkan sesuai dengan setting pembelajaran yang dilakukan. Metode pembelajaran yang bervariasi ini akan mendidik siswa menjadi kreatif, inovatif, dan percaya diri. 
Keempat, penilaian yang didasarkan atas proses dan hasil belajar. Sistem penilaian yang dilakukan dalam hal ini bersifat komprehensif, yang tidak hanya menilai prestasi belajar siswa saja, tetapi juga proses pembelajaran serta hasilhasil belajar yang dicapai. Hal ini memungkinkan untuk mendapatkan hasil penilaian yang lebih dekat dengan kemampuan sebenarnya, karena mengukur kemampuan dari berbagai aspek siswa, tidak hanya mengukur kemampuan spesifik secara parsial. Penilian pada model ini sering disebut sebagai model penilaian kinerja atau performance assessment, yang dilakukan secara berkelanjutan dan menyeluruh.

\section{Penutup}

Bahasa merupakan salah satu bagian penting di dalam masyarakat dan bermasyarakat, bahkan bahasa tidak bisa dipisahkan dari masyarakat. Di mana ada masyarakat, maka di situ akan ada bahasa, dan sebaliknya, di mana ada bahasa di situ pasti ada masyarakat bahasa yang menggunakannya sebagai alat berinteraksi. Jika dikaji lebih mendalam, maka komponen-komponen dari masyarakat di antaranya adalah adanya sekumpulan orang, yang menduduki suatu areal tertentu, memiliki kultur yang sama, menjunjung nilai-nilai dan norma-norma yang sama, serta saling berinteraksi. Interaksi yang dilakukan antara anggota masyarakat dengan menggunakan bahasa, sehingga jelaslah bahwa bahasa merupakan bagian dari mayarakat.

Uraian di atas telah dipaparkan berbagai konsep sosiolinguistik yang mendasari strategi pembelajaran bahasa di sekolah. Namun demikian, dari seluruh pemaparan hanya nampak kelebihan proses pembelajaran dengan pendekatan komunikatif dan pengajaran berbasis kompetensi. Sebagai akhir dari tulisan ini, penulis mengemukakan beberapa pertanyaan yang perlu untuk dikaji lebih lanjut, yaitu: (1) Ada berapa orang guru di Indonesia yang mampu mejalankan proses pembelajaran seperti tersebut di atas dengan baik? (2) Bagaimana penerapannya di dalam sistem pendidikan Indonesia dengan kapasitas kelas yang (umumnya) terlalu besar? (3) Apakah publik sudah menyediakan fasilitas pendukung pembelajaran yang memadai? (4) Apakah pemerintah konsisten dalam mengimplementasikan kurikulum yang diterbitkannya berdasarkan konsep pendidikan berstandar nasional (termasuk sistem peng ukuran yang dipakai)? 


\section{DAFTAR RUJUKAN}

Aitchison, J. 1978. The ArticulateMammal. New York: Mc Graw-Hill Book Company.

Brown, R., and Gilman, A. 1972. The Power and Solidarity: Language and Sosial Context. Pier Paulo Giglioli, Midlesex: Penguin Book Ltd.

Fishman, J. A. 1972. Language in Sociocultural Change. Stanford, California: Stanford University Press.

Holmes, J. 2001. An Introduction to Sociolinguistics. England: Pearson Education Limited.

Hymes, D. 1974. Foundation in Sociolinguistics: An Ethnoghraphic Approach. Philadelphia: University of California Press.

Hymes, D. 1987. On Communicative Competence. Dalam The Communicative Approach to Language Teaching, C.J Brumfit and K. Johnson, USA: Oxford University Press.

Ibrahim, S. 1984. Telaah Kurikulum SMP. Surabaya: Usaha Nasional

Joyce, B., dan Weil, M. 2000. Models of Teaching. London: Allyn and Bacon.

Kartomiharjo, S. 1991. Culture in Foreign Language Class. Malang: English Department.

McNeil, J. D. 1996. Curriculum: A Comprehensive Introduction. University of Californmia, Los Angeles: Harper Collins College Publisher.

Milroy, L. 1990. Language and Sosial Networks. Oxford, England: Basil Blackwell Publisher.

Mulyasa, E. 2004. Kurikulum Berbasis Kompetensi: Konsep, Karakteristik dan Implikasi. Bandung: PT Remaja Rosdakarya.

Muslich, M. 1994. Dasar-dasar Pemahaman Kurikulum 1994. Malang: YA3.

Nurhadi. 2004. Kurikulum 2004. Jakarta: PT Gramedia Widiasarana Indonesia.

Oliva, P. F. 1982. Developing the Curriculum. Georgia Sothern College, Boston: Little, Brown and Company.

Pride, J. B. and Holmes, J. 1972. Sociolinguistics. Middlesex, London: Penguin Book Limited. 
Richards, J. C. and Rodgers, T. 2001. Approaches and Methods in Language Teaching. Cambridge: Cambridge University Press.

Richards, J. C. 2001. Curriculum and Material Developmen for English Teaching. Cambridge: Cambridge University Press.

Rivers, W. M. 1996. Interactive Language Teaching. Cambridge: Cambridge Language Teaching Library.

Smolinsky, F. 1985. Landmarks of American Language and Linguistics. Washington DC: United Staes Information Agency.

Soebroto, S. 2007. Temuan Linguistik untuk Pengajaran Bahasa. Surakarta: Universitas Negeri Sebelas Maret.

Trudgil, P. 1974. Sociolinguistic: An Introduction. Middlesex, London: Penguin Book Limited. 